TANTALUM AS AN INDICATOR ELECTRODE IN DIFFERENT S...... 71

TANTALUM AS AN INDICATOR ELECTRODE IN DIFFERENT

POTENTIOMETRIC TITRATIONS

ENAS M. ATTIA

Chemistry Department, Faculty of Science (Girls), Al- Azhar University, Cairo, Egypt.

\begin{abstract}
Tantalum metal was employed as an indicator electrode in different potentiometric titrations. Silver, platinum and SCE were successfully applied as reference electrodes. A number of classical acid/base reactions were chosen. This involve titration of strong and weak mono- and poly basic acids; $\mathrm{HCl}, \mathrm{H}_{2} \mathrm{SO}_{4}, \mathrm{H}_{3} \mathrm{PO}_{4}$, $\mathrm{HCOOH}$ and $\mathrm{H}_{2} \mathrm{C}_{2} \mathrm{O}_{4}$ with $\mathrm{NaOH}$ and $\mathrm{NH}_{4} \mathrm{OH}$. Both forward and backward titrations were carried out. The titration performed until the greatest jump of potential appeared by adding one drop of titrant. Both forward and backward titration curves showed marked potential inflexions which recorded at the theoretically calculated equivalence points. Bimetallic combinations were equally suitable for the determination of equivalence points of acids neutralizing in more than one step, e.g., $\mathrm{H}_{3} \mathrm{PO}_{4}$ but not with oxalic acid.

The titrations of $\mathrm{S}_{2} \mathrm{O}_{3}$-with $\mathrm{I}_{2}$ solution using the different tantalum systems were equally successful; sharp potential jumps and distinct end points were obtained. Moreover the potential changes at the same direction as that of Pt/SCE system. On the other hand, when ferrous iron reacted with permanganate, a $\mathrm{Ta} / \mathrm{Pt}$ system gave a potential responsive to $\mathrm{Fe}^{+2}$ concentrations. The titration curves obtained exhibited regular defined and sharp inflexion points with high potential drop at the equivalence point. This potential drop had a reverse direction compared with that of $\mathrm{Pt} / \mathrm{SCE}$ system. While on titrating $\mathrm{Fe}^{++}$ions with dichromate solution, the curves had no distinct end points at any of the examined systems. These systems successes also to define the end point in the titration of $\mathrm{FeCl}_{3}$ against $\mathrm{NaOH}$ solution.
\end{abstract}

\title{
Introduction
}

In a potentiometric titration the endpoint is determined by the use of a pair of electrodes or a combination electrode. The endpoint occurs where there is a maximal rate of change of potential at the endpoint of the titration. In the portion of the curve corresponding to this large change in potential, there is a point at which the curve changes its direction of curvature. This point is an inflection point or break in the curve and ideally it occurs at the equivalence point of the titration [1]. However, in certain cases, there may be a bias in the analysis, and the break may be slightly displaced from the true equivalence point [2]. The electrodes for potentiometric titrations are chosen so that a change in potential of the titration solution, caused by titration of the analyte of interest, is optimally detected. Indicator electrodes qualify 
certain requirements depending on the reaction to be tested. In neutralization reactions, the electrode should be both acid and alkali resistant, and respond linearly to variations in $\mathrm{pH}[3,4]$. In redox titrations, the metal oxide layer must possess high electrical conductance. The tantalum electrode and a large number of metal- metal oxide electrodes are commonly used in this type of titrations [5,6]. A potentiometric titration technique has a variety of important applications in our life, it was used for characterizing vegetable oil quality control (olive and seed oils) [7]. Equilibrium studies on the nickel(II) complexes of oxygen, nitrogen and thioether sulfur donor ligands were performed by potentiometric titration [8]. Also, the equilibria of the complexation processes of $\mathrm{V}^{3+}$ with aromatic amino acids [9] , the protonation and stability constants toward $\mathrm{Co}^{2+}, \mathrm{Ni}^{2+}, \mathrm{Cu}^{2+}, \mathrm{Zn}^{2+}, \mathrm{Cd}^{2+}$ and $\mathrm{Pb}^{2+}$ were determined by potentiometric technique[10]. Determination of chlorine and dissolved oxygen in waters by iodimetric potentiometric titration using a membrane containing poly vinyl chloride and 2-nitrophenyl octyl ether as plasticizer was determined by means of potentiometric measurements [11]. PVC based liquid membrane electrode coatings is also used in potentiometric detection for a series of substances in cationexchange systems [12]. This technique has greatest applications in evaluating the detection limit in ion selective electrodes [13-16] and in determining the low concentrations of anionic [17-21] and cationic surfactants [22].

Acid/ base potentiometric titrations have been recently used to determine the dissociation constants of carboxylic groups [23] and to determine the copolymer compositions of $\mathrm{N}$-isopropylacrylamide and itaconic acid [24]. The amount of surface active $-\mathrm{OH}$ groups and surface charge density on the red mud particles generated from Chinese diaspore bauxite were also evaluated from the acid/basic potentiometric titration data in $0.5 \mathrm{~mol} / \mathrm{L} \mathrm{NaCl}$ solution [25]. The use of $\mathrm{Ta} / \mathrm{Ta}_{2} \mathrm{O}_{5}$ electrode as an indicator electrode in potentiometric acid-base titrations in fused $\mathrm{KNO}_{3}$ [26] and as a $\mathrm{pH}$ indicator electrode in aqueous media [27] was of great interest.

The purpose of the present work is to establish the feasibility of tantalum metal as an indicator electrode with SCE as a reference electrode; and both of Ta/Pt and $\mathrm{Ta} / \mathrm{Ag}$ bimetallic combinations to be used for potentiometric determination of equivalence points in different types of reactions. 
TANTALUM AS AN INDICATOR ELECTRODE IN DIFFERENT S....... 73 Experiment

\section{Preparation of the indicator-electrode}

The tantalum electrode was prepared from a cylindrical rod of spectroscopically pure tantalum metal of $0.096 \mathrm{~cm}^{2}$ area supplied by Johnson Matthey, England. A stout copper wire lead was affixed at one end by mechanical jamming. The electrode surface was mechanically polished using 320, 600, 800 and 1000 grid emery papers. Then, it was rubbed against soft cloth to acquire a silvery bright appearance.

\section{Preparation of reference and metal electrodes}

The potential was measured relative to saturated calomel electrode (SCE). A silver wire electrode of $0.12 \mathrm{~cm}^{2}$ area was cleaned to brightness using silver polish on a damp tissue. Platinum sheet with area of $4 \mathrm{~cm}^{2}$ was cleaned using an aluminum oxide polishing strip. The electrodes were thoroughly rinsed with bidistilled water.

\section{Preparation for titration}

The chemicals required were of analytical reagent grade and were prepared by dilution from a concentrated stock solution and standardized according to recommended procedures [28]. Solutions were stirred on a magnetic stirrer, the electrodes and burette tip were immersed in the solutions. The stirrer speed was adjusted to stir rapidly without splashing or creating a vortex.

The titrant was added in a dosage rate of $0.5 \mathrm{ml} / \mathrm{min}$. The meter readings were taken with each succeeding $0.2 \mathrm{ml}$ increment with making at least from five to ten more additions of titrant before ending the titration. Each system was titrated at least three times to ensure reproducibility. An initial titration was done. This allowed the electrode the opportunity to become equilibrated in the system in which it will be used discarding the results from this initial titration. For the sake of comparison, the titrations were followed simultaneously with Pt/ SCE cell.

In forward titrations, the base was added to $3 \mathrm{ml}$ of the acid whereas the reverse was done in the backward titrations. In each experiment, tantalum electrode was left in the solution to be titrated till the establishment of the steady state potential. The oxidation- reduction study involved the titration of $\mathrm{I}_{2}$ solution with $\mathrm{Na}_{2} \mathrm{~S}_{2} \mathrm{O}_{3}$ and titration of $\mathrm{Fe}\left(\mathrm{NH}_{4}\right)_{2}\left(\mathrm{SO}_{4}\right)_{2}$ against $\mathrm{KMnO}_{4}$ and $\mathrm{K}_{2} \mathrm{Cr}_{2} \mathrm{O}_{7}$. With all reagents both 
forward (in which oxidant is the titrant) and backward (in which the reducing agent is the titrant) titrations, were carried out. Sodium hydroxide solutions were prepared from carbonate- free $\mathrm{NaOH}$ and standardized against oxalic acid using phenolphthalein indicator in order to precipitate ferric iron from $\mathrm{FeCl}_{3}$ solution. The EMF is plotted against the volume of titrant. A digital potentiometer with a sensitivity of $0.1 \mathrm{mV}$ (KEITHLEY, model 175, USA) was used for potential measurements.

\section{Results and Discussion}

\section{Neutralization reactions}

In forward titrations of all acids under test, the potential of tantalum electrode relative to that of SCE, Pt or Ag is somewhat of a negative value at the beginning of the neutralization. However, this potential becomes more negative as the neutralization goes to its completion. The titration curves are characterized by a single potential inflexion at the equivalence point. $\mathrm{HCl}$ is a mineral acid which appears to be completely ionized in water according to the reaction:

$$
\mathrm{HCl}+\mathrm{H}_{2} \mathrm{O}=\mathrm{H}_{3} \mathrm{O}^{+}+\mathrm{Cl}^{-}
$$

For potentiometric titration of $\mathrm{HCl}$ against $\mathrm{NaOH}$ (Figure 1), the stoichiometric point is at $\left[\mathrm{H}^{+}\right]=\left[\mathrm{OHJ}=1 / 2 \mathrm{~K}_{\mathrm{w}}=7\right.$ since at this point the solution contains the ions of $\mathrm{NaCl}$ which does not change the reaction of pure water [29]. The behavior of $\mathrm{H}_{2} \mathrm{SO}_{4}$ is similar to that of $\mathrm{HCl}$ (Figure 2). 
TANTALUM AS AN INDICATOR ELECTRODE IN DIFFERENT S....... 75

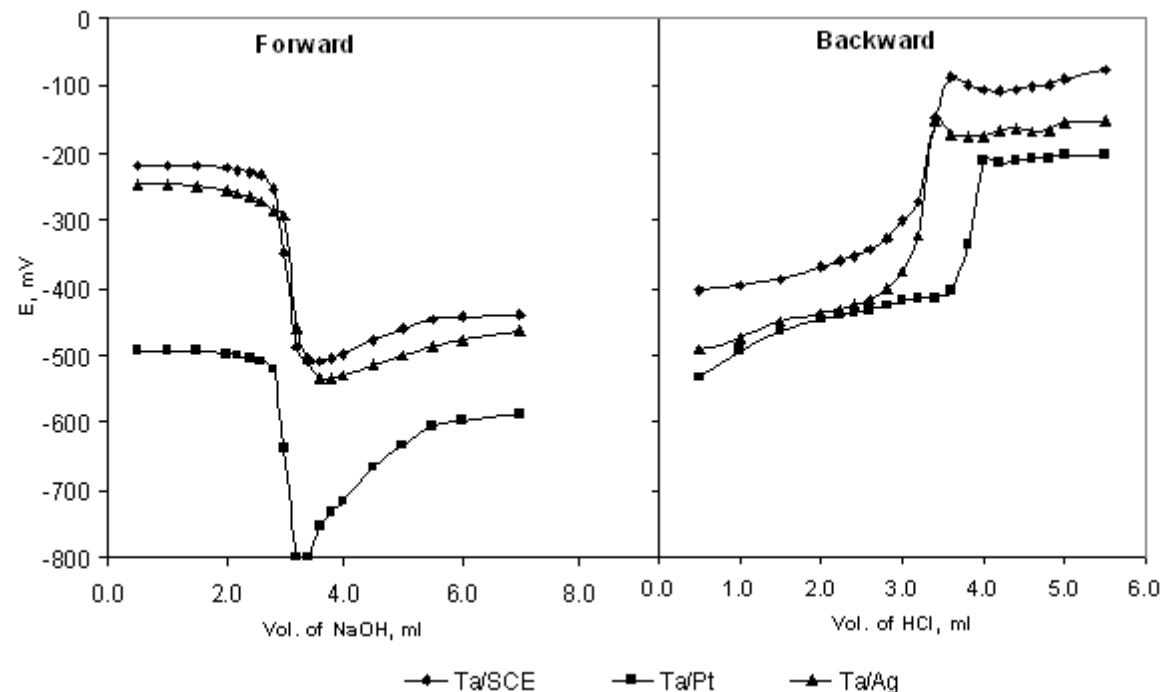

Figure (1): Forward and backward potentiometric titration curves of 0.0799N $\mathrm{HCl}$ \# $0.0857 \mathrm{~N}$ NaOH solution.

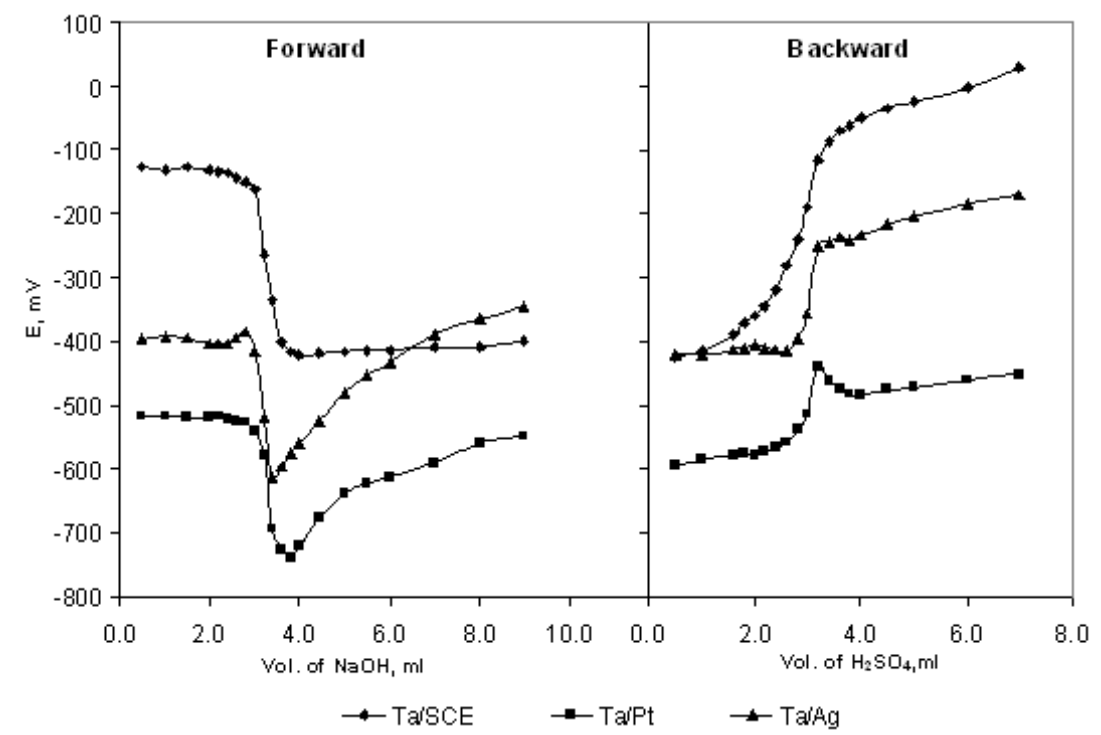

Figure (2): Forward and backward potentiometric titration curves of $0.0943 \mathrm{~N} \mathrm{H}_{2} \mathrm{SO}_{4} \#$ $0.0857 \mathrm{~N}$ NaOH solution.

Forward titration curves of phosphoric acid against $\mathrm{NaOH}$ solution using the different electrode systems are characterized by two potential inflexions (Figure 3). 


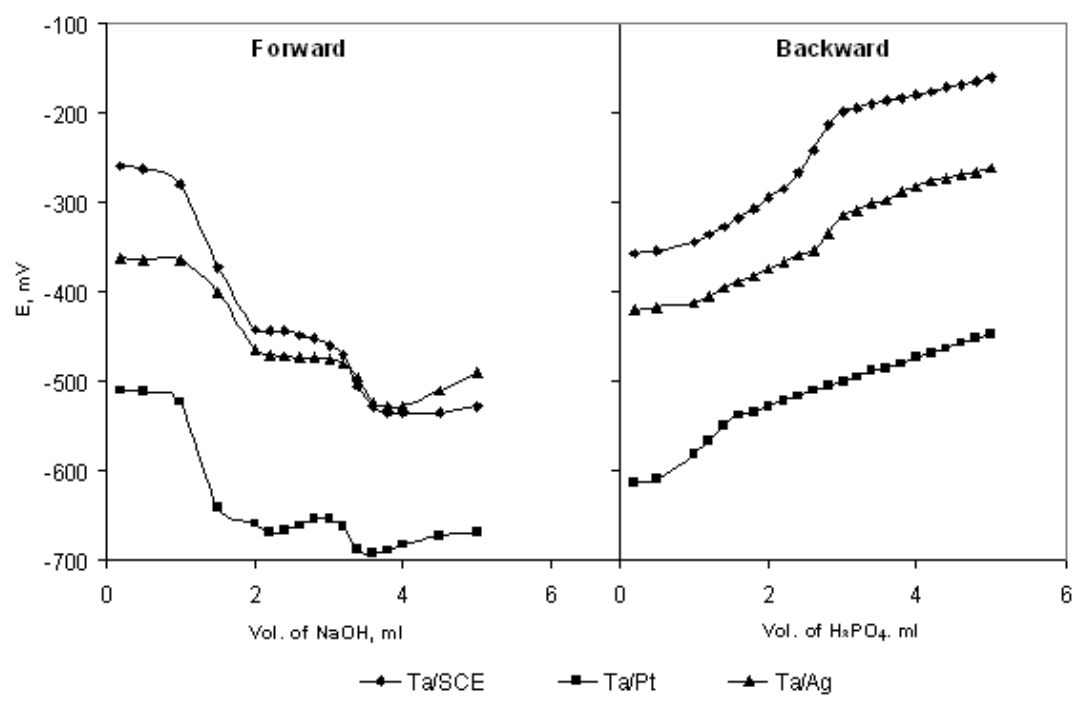

Figure (3): Forward and backward potentiometric titration curves of $0.0914 \mathrm{~N}_{3} \mathrm{PO}_{4} \#$ $0.0857 \mathrm{~N} \mathrm{NaOH}$ solution.

The first inflexion corresponds to one- third of the total replaceable hydrogen. The second appears after two thirds of the replaceable hydrogen has been titrated. The uptake of the titrant along the two steps is equal and corresponds to 1 mole $\mathrm{NaOH} / 1$ mole $\mathrm{H}_{3} \mathrm{PO}_{4}$, representing the successive formation of mono- and di- basic salts according to:

$$
\text { And } \begin{aligned}
\mathrm{H}_{3} \mathrm{PO}_{4}+\mathrm{OH}_{2}^{-} & =\mathrm{H}_{2} \mathrm{PO}_{4}^{-}+\mathrm{OH}^{-}=\mathrm{H}_{2} \mathrm{O} \\
& =\mathrm{HPO}_{4}{ }^{-2}+\mathrm{H}_{2} \mathrm{O}
\end{aligned}
$$

The splitting of the two neutralization steps is in accordance with the marked difference between $\mathrm{K}_{1}$ and $\mathrm{K}_{2}$ of $\mathrm{H}_{3} \mathrm{PO}_{4}$, which are amounting to $1.1 \times 10^{-2}$ and $7.5 \times 10^{-8}$ respectively [29]. No inflexion 
TANTALUM AS AN INDICATOR ELECTRODE IN DIFFERENT S....... 77 is recorded corresponding to the third ionization. This is because the last third of the hydrogen of phosphoric acid is so slightly ionized and the ionization constant is so near that of water $\left(\mathrm{K}_{3}=\right.$ $\left.5.0 \times 10^{-13}\right)$. In back titrations there are no sharp change in potential (as in forward titration) with small additions of acid near the end point.

Despite of oxalic is a dibasic acid with $\mathrm{K}_{1}=3.8 \times 10^{-2}$ and $\mathrm{K}_{2}=6.1$ $x 10^{-5}$ [29] which are neutralized along two well defined steps, only one neutralization step is recorded (Figure 4). This step corresponds to reaction of 2 mole $\mathrm{NaOH} / 1$ mole acid, which reflects the failure of these combinations to split the two neutralization steps.

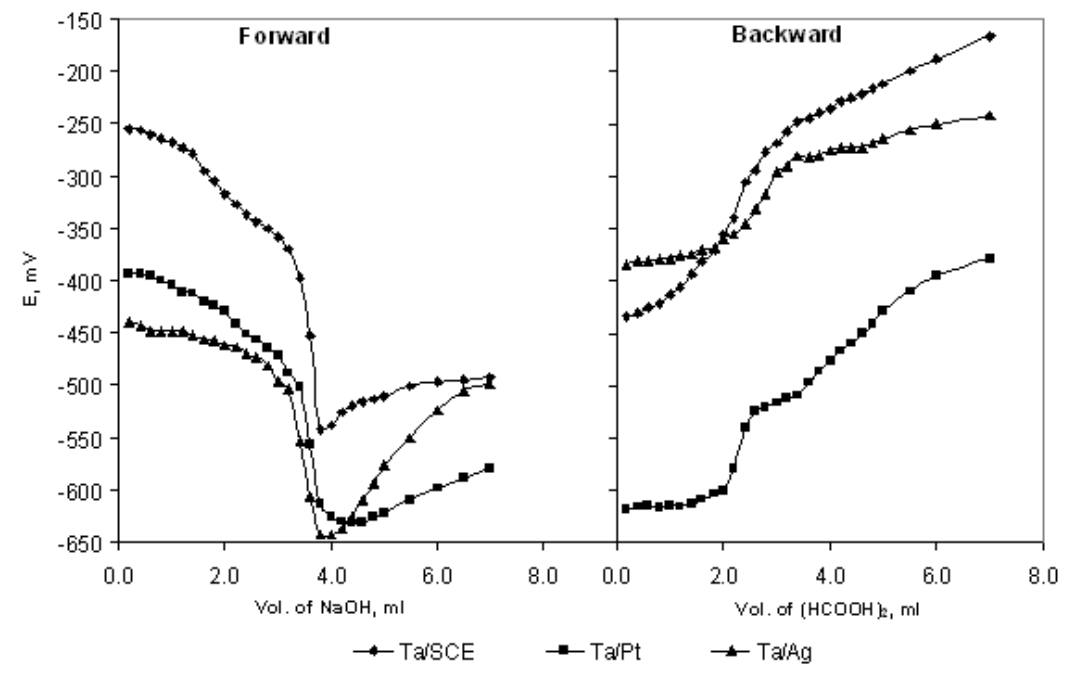

Figure (4): Forward and backward potentiometric titration curves of $3 \mathrm{ml} 0.1 \mathrm{~N} \mathrm{H}_{2} \mathrm{C}_{2} \mathrm{O}_{4} \#$ $0.0857 \mathrm{~N} \mathrm{NaOH}$ solution.

Formic acid is a weak acid $\left(\mathrm{K}_{\mathrm{a}}=1.8 \times 10^{-4}\right)$. At the equivalence point, there is a solution of sodium formate of some particular concentration [29]:

$$
\begin{aligned}
& \mathrm{H}_{2} \mathrm{O} \\
& \downarrow \uparrow \\
& \mathrm{Na}^{+}+\mathrm{HCOO}^{-}+\mathrm{H}^{+}+\mathrm{OH}^{-} \rightleftarrows \mathrm{Na}^{+}+\mathrm{OH}^{-}+\mathrm{H}^{4)}(\mathrm{OH}
\end{aligned}
$$


However, in case of formic acid the value of potential inflexion is the smallest one corresponding to all other acids (Figure 5). Table 1 illustrates the height of potential jump for all systems used in forward titration descending in the following order:

$$
\mathrm{HCl}>\mathrm{H}_{2} \mathrm{SO}_{4}>(\mathrm{COOH})_{2}>\mathrm{H}_{3} \mathrm{PO}_{4}>\mathrm{HCOOH}
$$

This is attributed to the considerable difference in the strengths of these acids which follow the same order i.e. pK $=-7,-2,1.23$, 2.12 and 3.75 for hydrochloric, sulfuric, oxalic, phosphoric and formic acid respectively [30].

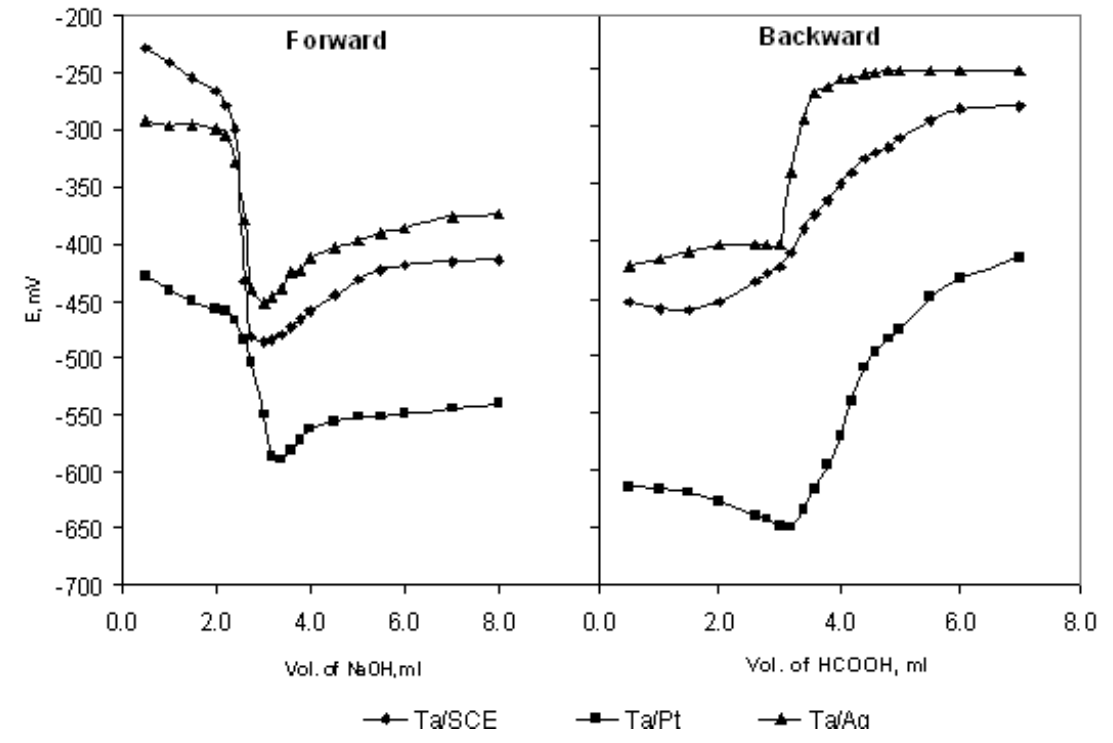

Figure (5): Forward and backward potentiometric titration curves of 0.0714N HCOOH \# 0.0857N NaOH solution.

When $\mathrm{HCl}$ is titrated with $\mathrm{NH}_{4} \mathrm{OH}$ using the different electrode systems, the forward and backward titration curves are characterized by presence of a single potential inflexion at the equivalence point (Figure 6). The potential inflexions at the two cases are smaller than that obtained in the titration of $\mathrm{HCl}$ against $\mathrm{NaOH}$ solution. This is attributed to the difference in strengths between the two bases. 


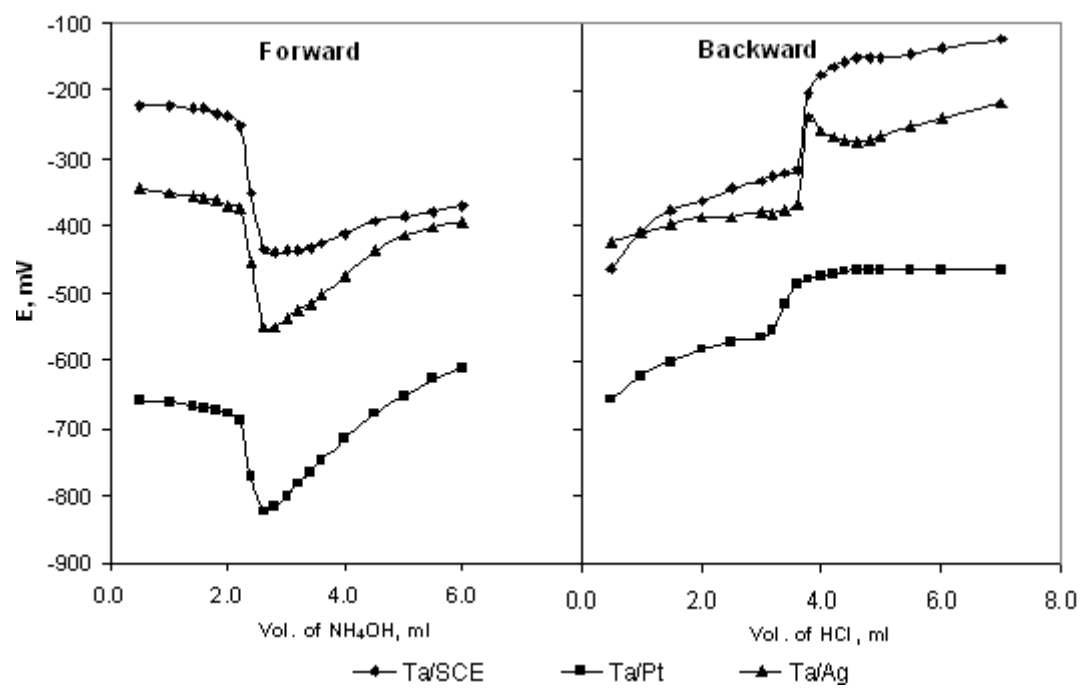

Figure (6): Forward and backward potentiometric titration curves of $0.0799 \mathrm{~N}$ $\mathrm{HCl}$ \# 0.103N $\mathrm{NH}_{4} \mathrm{OH}$ solution.

Table 1: comparison of different electrode systems in aqueous acid- base titrations

\begin{tabular}{|c|c|c|c|c|c|c|c|c|c|}
\hline & \multirow{3}{*}{$\begin{array}{c}\text { Type of } \\
\text { acid }\end{array}$} & \multirow{3}{*}{$\begin{array}{c}\text { Type } \\
\text { of } \\
\text { base }\end{array}$} & \multirow{3}{*}{$\begin{array}{c}\text { Syste } \\
\text { m }\end{array}$} & \multicolumn{3}{|c|}{ Forward } & \multicolumn{3}{|c|}{ Backward } \\
\hline & & & & \multirow{2}{*}{$\begin{array}{c}P_{j} \\
m V\end{array}$} & \multicolumn{2}{|c|}{$\mathrm{V}_{\mathrm{eq}}, \mathrm{ml}$} & \multirow{2}{*}{$\begin{array}{c}\mathrm{P}_{\mathrm{j}} \\
\mathrm{mV}\end{array}$} & \multicolumn{2}{|c|}{$\mathrm{V}_{\mathrm{eq}}, \mathrm{ml}$} \\
\hline & & & & & $\mathrm{Ca}$ & Ex & & $\mathrm{Ca}$ & Ex \\
\hline \multirow[t]{3}{*}{$\begin{array}{c}\text { Strong } \\
\text { acids }\end{array}$} & $\mathrm{HCl}$ & $\mathrm{NaOH}$ & $\begin{array}{c}\mathrm{Ta} / \mathrm{SC} \\
\mathrm{E} \\
\mathrm{Ta} / \mathrm{Pt} \\
\mathrm{Ta} / \mathrm{Aa}\end{array}$ & $\begin{array}{l}254 \\
278 \\
243\end{array}$ & 2.8 & $\begin{array}{l}3.2 \\
3.0 \\
3.2\end{array}$ & $\begin{array}{l}186 \\
192 \\
215\end{array}$ & 3.2 & $\begin{array}{l}3.3 \\
3.8 \\
3.3\end{array}$ \\
\hline & $\mathrm{H}_{2} \mathrm{SO}_{4}$ & $\mathrm{NaOH}$ & $\begin{array}{c}\mathrm{Ta} / \mathrm{SC} \\
\mathrm{E} \\
\mathrm{Ta} / \mathrm{Pt} \\
\mathrm{Ta} / \mathrm{Ag}\end{array}$ & $\begin{array}{l}242 \\
212 \\
228\end{array}$ & 3.3 & $\begin{array}{l}3.5 \\
3.3 \\
3.2\end{array}$ & $\begin{array}{l}274 \\
118 \\
166\end{array}$ & 2.7 & $\begin{array}{l}2.8 \\
3.1 \\
3.1\end{array}$ \\
\hline & $\mathrm{H}_{3} \mathrm{PO}_{4}$ & $\mathrm{NaOH}$ & $\begin{array}{c}\mathrm{Ta} / \mathrm{SC} \\
\mathrm{E} \\
\mathrm{Ta} / \mathrm{Pt} \\
\mathrm{Ta} / \mathrm{Ag}\end{array}$ & $\begin{array}{l}164,66 \\
137,34 \\
101,48\end{array}$ & $\begin{array}{c}1.4,3 \\
.4\end{array}$ & $\begin{array}{c}1.5,3 . \\
4 \\
1.3,3 . \\
3 \\
1.5,3 . \\
4\end{array}$ & $\begin{array}{c}96 \\
- \\
224\end{array}$ & 2.7 & $\begin{array}{c}2.6 \\
- \\
2.8\end{array}$ \\
\hline
\end{tabular}




\begin{tabular}{|c|c|c|c|c|c|c|c|c|c|}
\hline & $\mathrm{HCl}$ & $\mathrm{NH}_{4} \mathrm{OH}$ & $\begin{array}{c}\mathrm{Ta} / \mathrm{SC} \\
\mathrm{E} \\
\mathrm{Ta} / \mathrm{Pt} \\
\mathrm{Ta} / \mathrm{Ag} \\
\end{array}$ & $\begin{array}{l}184 \\
134 \\
174\end{array}$ & 2.3 & $\begin{array}{l}2.4 \\
2.4 \\
2.4\end{array}$ & $\begin{array}{c}113 \\
68 \\
130\end{array}$ & 3.9 & $\begin{array}{l}3.7 \\
3.4 \\
3.7\end{array}$ \\
\hline \multirow{2}{*}{$\begin{array}{l}\text { Weak } \\
\text { acids }\end{array}$} & $(\mathrm{COOH})_{2}$ & $\mathrm{NaOH}$ & $\begin{array}{c}\mathrm{Ta} / \mathrm{SC} \\
\mathrm{E} \\
\mathrm{Ta} / \mathrm{Pt} \\
\mathrm{Ta} / \mathrm{Ag}\end{array}$ & $\begin{array}{l}172 \\
144 \\
148\end{array}$ & 3.5 & $\begin{array}{l}3.7 \\
3.6 \\
3.4\end{array}$ & $\begin{array}{c}126 \\
76 \\
79\end{array}$ & 2.4 & $\begin{array}{l}2.2 \\
2.6 \\
2.3\end{array}$ \\
\hline & $\mathrm{HCOOH}$ & $\mathrm{NaOH}$ & $\begin{array}{c}\mathrm{Ta} / \mathrm{SC} \\
\mathrm{E} \\
\mathrm{Ta} / \mathrm{Pt} \\
\mathrm{Ta} / \mathrm{Ag}\end{array}$ & $\begin{array}{l}182 \\
118 \\
125\end{array}$ & 2.5 & $\begin{array}{l}2.5 \\
2.8 \\
2.6\end{array}$ & $\begin{array}{l}113 \\
183 \\
137\end{array}$ & 3.6 & $\begin{array}{l}3.6 \\
4.0 \\
3.2\end{array}$ \\
\hline
\end{tabular}

Ex, experimental

Table (1) illustrates the points of maximum inflexion in the titration curves were nearly identical with the theoretical quantities of the acids or bases necessary for neutralization process.

Analysis of a mixture of acids which differ greatly in their strengths, e.g. formic and hydrochloric acids using Ta/Ag system is illustrated in Figure 7. From the curves, the value of potential jump for titrating $2 \mathrm{ml}$ formic acid (solution $\mathrm{B}$ ) with $\mathrm{NaOH}$ solution is $164 \mathrm{mV}$ at equivalence volume of $1.8 \mathrm{ml}$. The highest potential jump $(271 \mathrm{mV}$ ) is reported when titrating $2 \mathrm{ml} \mathrm{HCl}$ (solution A) with $\mathrm{NaOH}$ at equivalence volume of $2.2 \mathrm{ml}$. This potential jump was decrease to $110 \mathrm{mV}$ when adding $4 \mathrm{ml}$ formic acid to $2 \mathrm{ml} \mathrm{HCl}$ (solution $\mathrm{C}$ ) at equivalence volume of $5.8 \mathrm{ml}$, and to $150 \mathrm{mV}$ when $2 \mathrm{ml}$ formic acid is added to $4 \mathrm{ml} \mathrm{HCl}$ (solution D) at equivalence volume of $6 \mathrm{ml}$. The equivalence volumes of solutions $\mathrm{C}$ and $\mathrm{D}$ is nearly equivalent to the total volume of acidic solution used. Also, the potential jump in solution $\mathrm{D}$ is higher than that of solution $\mathrm{C}$ due to the increasing amount of stronger acid. Hence in the present study the two acids combined together and produce acidic solution with a new strength depends on the quantity of each acid present in solution. Finally, the system succeeded to detect the end point for a mixture of acids as a uniform solution but failed to analyze the components of the mixture. This behavior is attributed to the fact that, in the aqueous medium, it is impossible to obtain two or more inflections of the titration curve of a mixture of two or more acids or bases until the value of their pK greatly differ from one another [31]. For this analysis to be successful the two acids should differ in strength by at least $10^{5} / 1$ or the titration must be performed in non- aqueous media [31, 32]. 


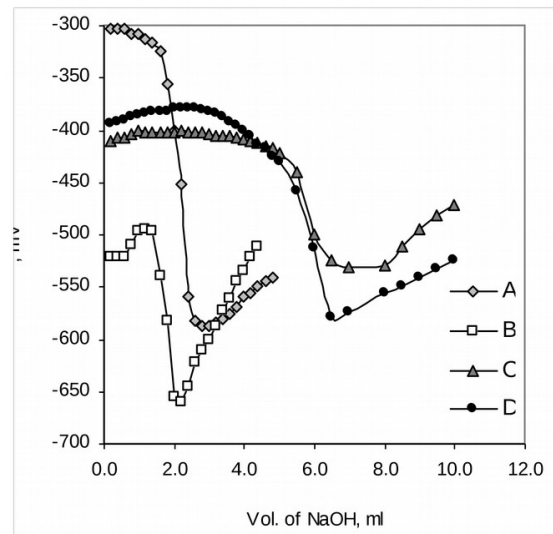

Figure (7): Potentiometric titration curves of mixture of $0.0714 \mathrm{~N} H C O O H$ and $0.0799 \mathrm{~N}$ HCl acids with $0.0857 \mathrm{~N} \mathrm{NaOH}$ using Ta/Ag system (A: $2 \mathrm{ml} \mathrm{HCl,} \mathrm{B:} 2 \mathrm{ml}$ formic, C: $2 \mathrm{ml} \mathrm{HCl}+4 \mathrm{ml}$ formic, $\mathrm{D}: 2 \mathrm{ml}$ formic $+4 \mathrm{ml} \mathrm{HCl}$ ).

\section{2- Oxidation reactions}

Normal titration curves were obtained when $\mathrm{S}_{2} \mathrm{O}_{3}$ is titrated with $\mathrm{I}_{2}$ solution using the different Ta- systems. The potential starts from negative values and become more positive upon the addition of the oxidizing agent (Figure 8). The potential changes at the equivalence point are close to the standard potential of the concerned redox couples. The behavior obtained for different tantalum systems could be attributed to the fact that the standard potential of $\mathrm{I}_{2} / \mathrm{I}^{-}$and $\mathrm{S}_{2} \mathrm{O}_{3} / \mathrm{S}_{4} \mathrm{O}_{6}{ }^{-}$couples, viz. +0.62 and $+0.08 \mathrm{~V}$ coincide with the potential range where oxide formation or $\mathrm{H}_{2}$ evolution are not feasible. Thus, the results obtained using tantalum electrode may be explained on the same ground. This interpretation agrees with the previous findings of Saleh [33] for molybdenum disilicide electrode. The determining factor in redox reactions is the ratio of the concentration of the oxidized and reduced forms of the ionic species. The potential, E, acquired by the tantalum electrode at $25^{\circ} \mathrm{C}$ is given by:

$$
\mathrm{E}=\mathrm{E}^{\circ}+\frac{0.0591}{\mathbf{n}} \log \frac{[\mathrm{Ox}]}{[\operatorname{Red}]}
$$

The potential of the immersed Ta electrode is thus controlled by the ratio of these concentrations. During the oxidation of a reducing agent (forward) or reduction of 
an oxidizing agent (backward), the ratio and therefore the potential changes more rapidly in the vicinity of the end point of the reaction.
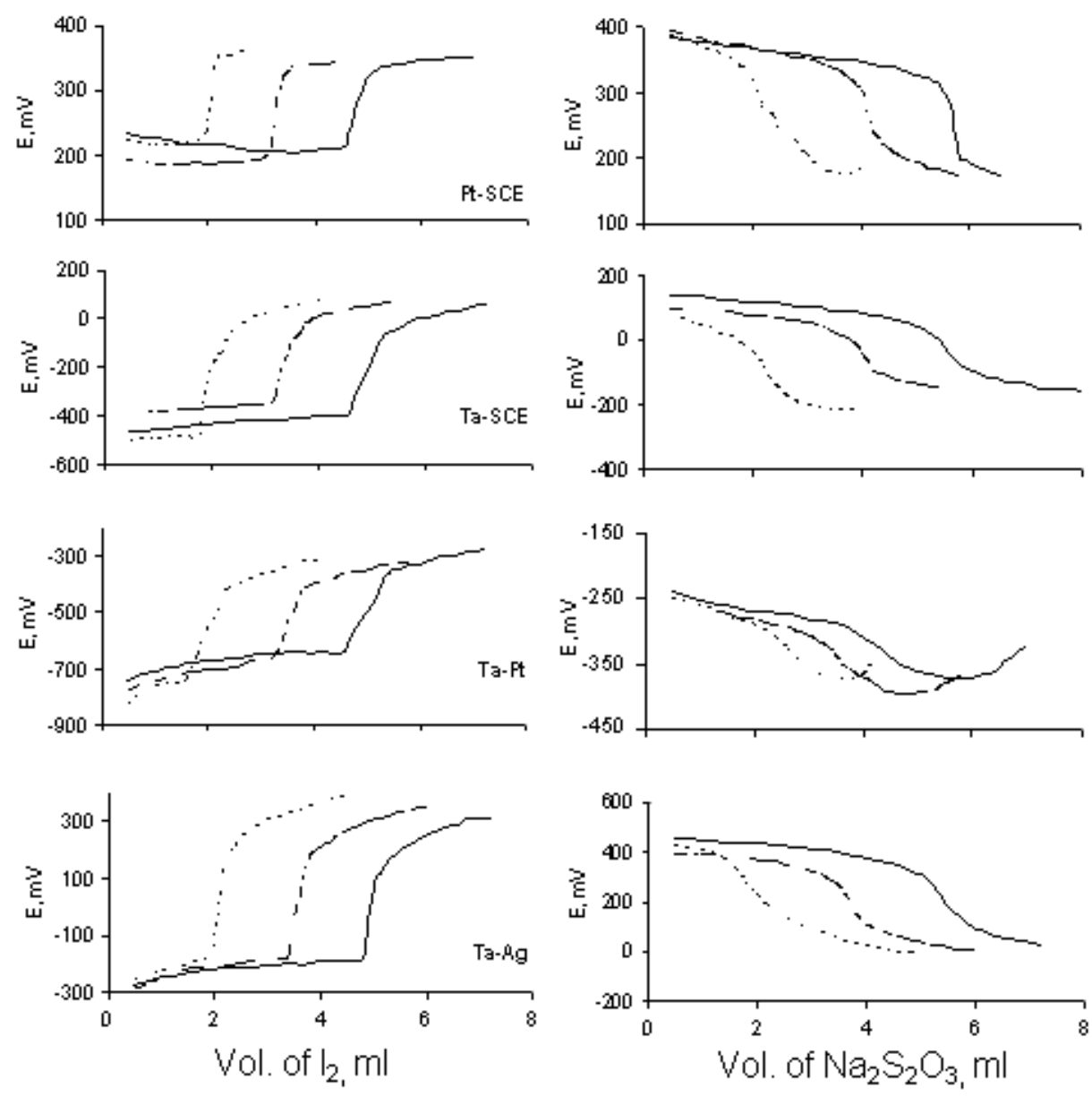

$2.0 \mathrm{ml}$

$.3 .5 \mathrm{ml}$ $5.0 \mathrm{ml}$

Figure (8): Forward and backward titration curves of 2.0, 3.5 and $5.0 \mathrm{ml}$ of $0.1 \mathrm{~N}$ $\mathrm{Na}_{2} \mathrm{~S}_{2} \mathrm{O}_{3}$ against $\mathrm{I}_{2}$ solutions.

Different behavior is noted when strong oxidizing agents like $\mathrm{MnO}_{4}-\bar{a}$ and $\mathrm{Cr}_{2} \mathrm{O}_{7}{ }^{2-}$ were used. Using Pt/SCE cell in the oxidation of $\mathrm{Fe}^{++}$with $\mathrm{KMnO}_{4}$ and $\mathrm{K}_{2} \mathrm{Cr}_{2} \mathrm{O}_{7}$ 
TANTALUM AS AN INDICATOR ELECTRODE IN DIFFERENT S....... 83

solutions illustrates a normal titration curves. Concerning forward titrations, tantalum electrode exhibits different potential values in the same direction as Pt/SCE system starting from lower values and becomes more positive as a result of the oxidizing agent addition (except for $\mathrm{Ta} / \mathrm{Pt}$ system in $\mathrm{KMnO}_{4}$ which behaves reversibly). However, reverse manner occurs in the backward titrations for the two oxidizing agents using Pt/SCE system and only for $\mathrm{KMnO}_{4}$ using Ta/SCE system (Figures 9 and 10).

In $\mathrm{KMnO}_{4}$ solution, the potential of Ta was measured relative to SCE and Ag in forward titration increases rapidly at the beginning reaching its maximum value followed by a steady state potential then another rapid increase in potential occurs. This may be attributed to that in forward titration; the potential of the electrode becomes more positive upon the addition of the oxidizing agent, until it reaches an equal or very close value to that of oxide film formation. Thereafter, the electrode potential is unaffected by further addition of the titrant which is represented by the steady state potential range in the curves. The final increase in potential may be owing to the formation of iron III sulfate hydrate precipitate. The potential continues to increase with increasing the amount of precipitate formed with each addition of $\mathrm{KMnO}_{4}$. Testing the possibility for detection of the end point from this plateau, the volume of the end point does not correspond to the highest potential before the steady part of the curves. The middle point of the steady part corresponds to the volumes: 6.25, 9.25, $12.5 \mathrm{ml}$. for Ta/SCE system and 4.75, 7.5and $9.5 \mathrm{ml}$. for Ta/Ag system in titrating 5, 10 and $15 \mathrm{ml}$. of $\mathrm{Fe}^{++}$solution. These volumes are so far from the calculated volumes which obtained by normal titration methods.

Back titrations using Ta/SCE achieve the right end point. While for $\mathrm{Ta} / \mathrm{Ag}$ system, the highest potentials (-43, -10 and -29) corresponding to 4,7 and $11 \mathrm{ml}$. respectively for titrating 5,10 and $15 \mathrm{ml}$ of $\mathrm{Fe}^{++}$are not accurate equivalence points.

On the other hand, in Ta/Pt system (forward titrations), the variation of the potential values of the indicator electrode with the quantity of oxidizing agent used follows typically the potentiometric titration curves. At the equivalence point, a sharp drop in the potential value of the indicator electrode occurs. This drop is in the reverse direction compared with that of $\mathrm{Pt} / \mathrm{SCE}$ system. A reverse behavior is 
observed with the back titrations. It was observed that a combination of a valve metal and a noble metal gives good results. This is attributed to the highest extent in electron conductivity possessed by such metal pair [34].
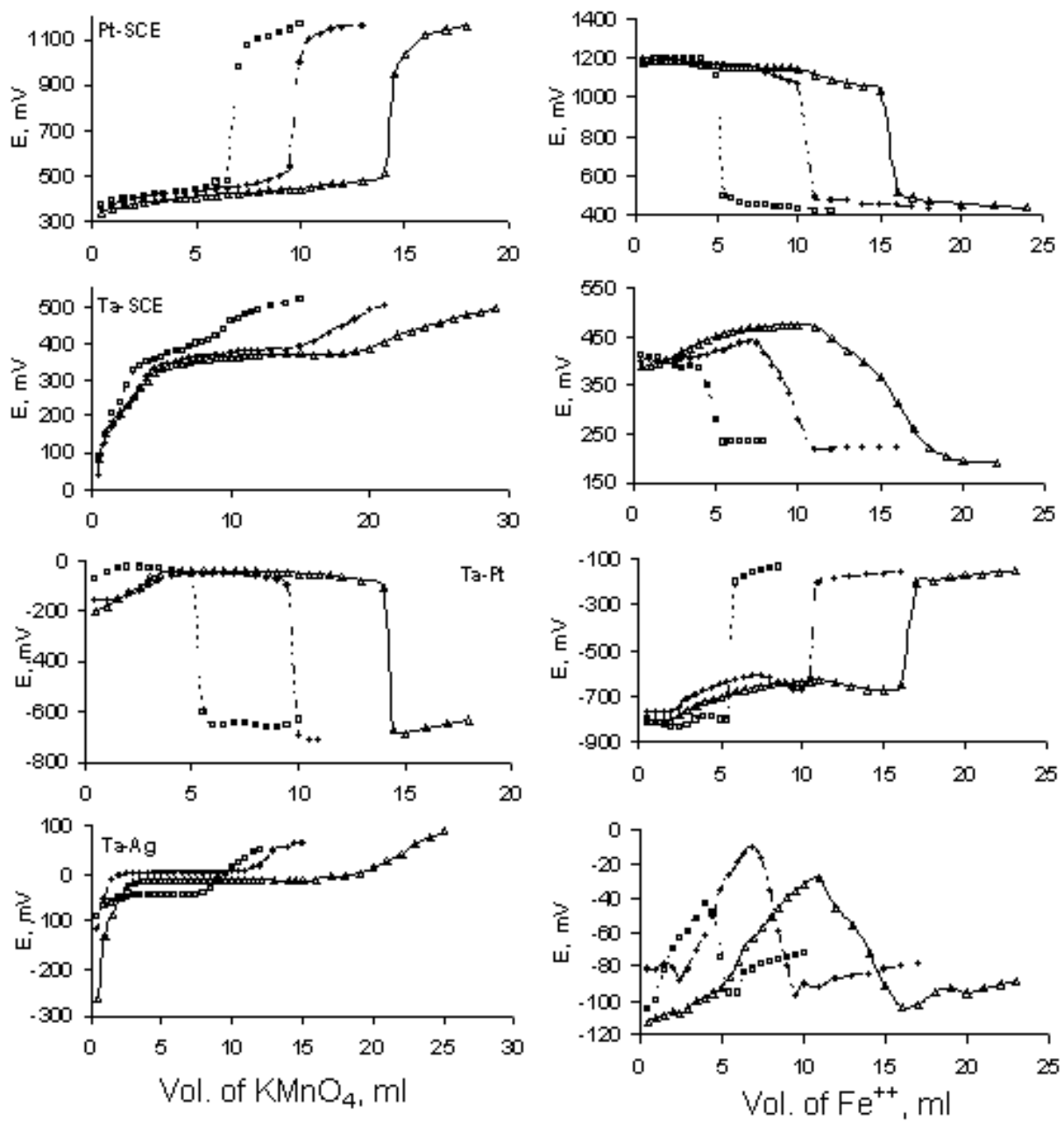

$$
\cdots+\cdots 5 \mathrm{ml} \quad-\cdot+-\cdot 10 \mathrm{ml} \longrightarrow 15 \mathrm{ml}
$$

Figure (9): Forward and backward titration curves of 5, 10 and $15 \mathrm{ml}$. of $0.1 \mathrm{~N}$ of $\mathrm{Fe}\left(\mathrm{NH}_{4}\right)_{2}\left(\mathrm{SO}_{4}\right)_{2}$ solution with $0.1 \mathrm{~N} \mathrm{KMnO}_{4}$ solution. 
TANTALUM AS AN INDICATOR ELECTRODE IN DIFFERENT S....... 85 Analyzing the forward curves of oxidation of $\mathrm{Fe}^{++}$with $\mathrm{K}_{2} \mathrm{Cr}_{2} \mathrm{O}_{7}$ by testing the volumes corresponded to the highest potential using $\mathrm{Ta} / \mathrm{SCE}, \mathrm{Ta} / \mathrm{Pt}$ and $\mathrm{Ta} / \mathrm{Ag}$ systems demonstrated that they are equal to: 4, 9, $14 \mathrm{ml}, 2,8,11 \mathrm{ml}$ and 3, 11, $14 \mathrm{ml}$ for titrating 5, 10, $15 \mathrm{ml}$ of $\mathrm{Fe}^{++}$, respectively (Figure 10). These volumes are far from the right ones which ranging about 5, 10 and $15 \mathrm{ml}$ respectively.
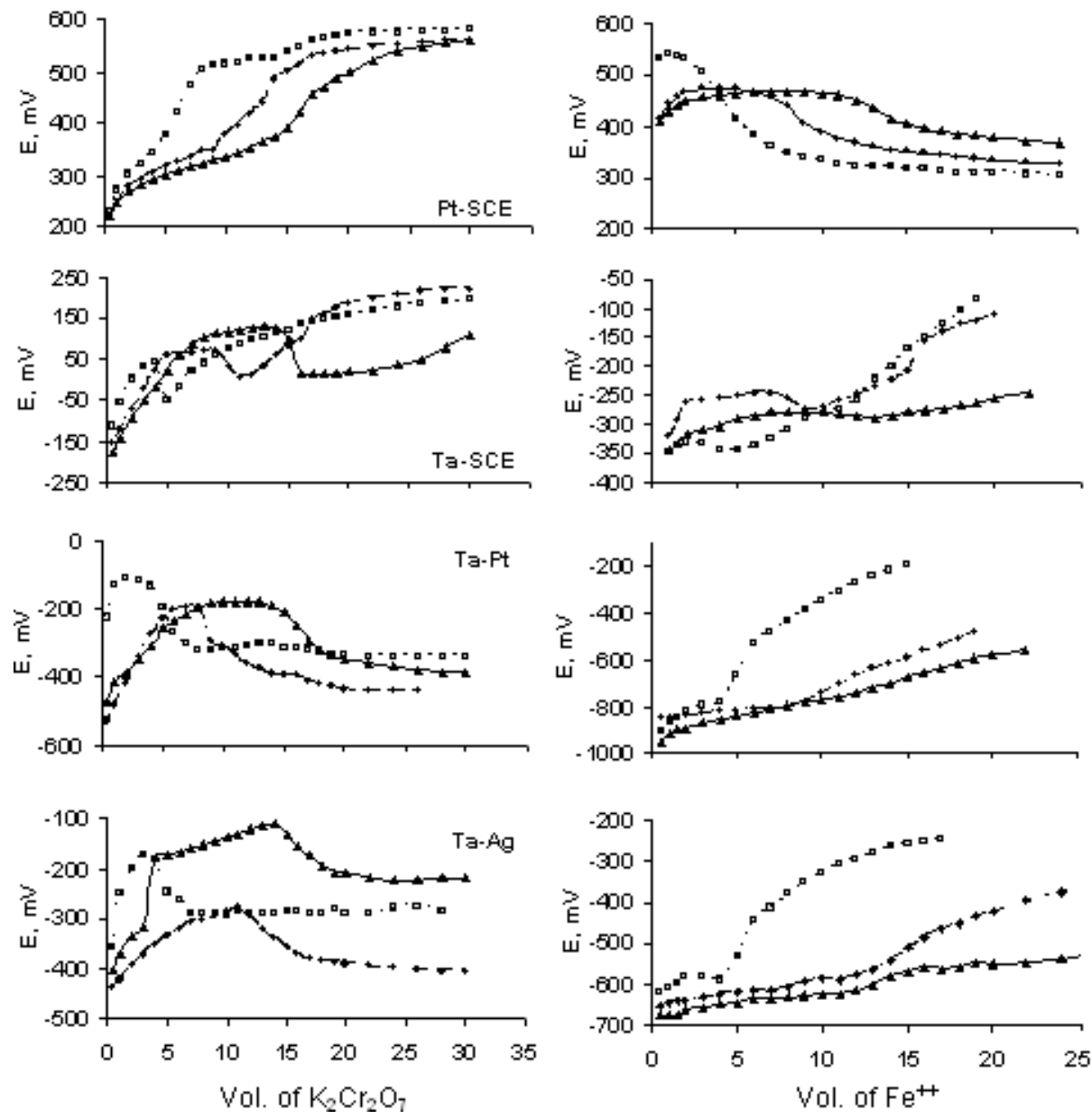

Figure (10): Forward and backward titration curves of 5, 10 and $15 \mathrm{ml}$. of $0.1 \mathrm{~N}$ of $\mathrm{Fe}\left(\mathrm{NH}_{4}\right)_{2}\left(\mathrm{SO}_{4}\right)_{2}$ solution with $0.1 \mathrm{~N} \mathrm{~K}_{2} \mathrm{Cr}_{2} \mathrm{O}_{7}$ solution.

The main product of tantalum is $\mathrm{Ta}_{2} \mathrm{O}_{5}$, which grows adhering to the metal substrate, but ruptures when a critical thickness is reached. This sequence of alternate growth and failure is repeated leading to a laminated scale. The thickening during the short 
adherent stages between the ruptures is parabolic [35]. It is assumed that the oxide dissociates into [5]:

$\mathrm{Ta}_{2} \mathrm{O}_{5}=2 \mathrm{Ta}^{5+}+5 \mathrm{O}^{2-}$

So, the potential of the tantalum electrode would be given by:

$$
\begin{aligned}
\mathrm{E}_{\mathrm{Ta}} & =\mathrm{E}^{\circ}{ }_{\mathrm{Ta} / \mathrm{Ta}}{ }^{5+}+(\mathrm{RT} / 10 \mathrm{~F}) \ln \left[\mathrm{Ta}^{5+}\right]^{2} \\
& =\mathrm{E}^{\circ}{ }_{\mathrm{Ta} / \mathrm{T}}{ }^{5+}+(\mathrm{RT} / 10 \mathrm{~F}) \ln \left(\mathrm{K}^{2}\left[\mathrm{O}^{2-}\right]^{5}\right)
\end{aligned}
$$

Where $K$, is the ionization constant of reaction (6).

In back titrations, the electrode is anodically polarized, by the oxidant, to the film formation value. Accordingly, it is already covered with metal oxide and hence does not respond to [Ox]/ [Red] variations.

The differences in potential of Ta electrode along the titration plateau in forward and backward curves reveal corresponding differences in the type of charge transfer in this electrode. The disparities in behavior of Ta electrode using $\mathrm{K}_{2} \mathrm{Cr}_{2} \mathrm{O}_{7}$ solutions are due to variations took place at the electrode surface.

The calculated potential jump in the different redox systems under test conditions were summarized in Table 2 . It was noted that, the three Ta-systems give excellent results with $\mathrm{S}_{2} \mathrm{O}_{3}-\mathrm{I}_{2}$ reaction in which the values of potential jump are higher than that of standard Pt/SCE system in both forward and backward titrations. On the other hand, the three systems failed in detecting the end point in oxidation of $\mathrm{Fe}^{+2}$ ions with $\mathrm{K}_{2} \mathrm{Cr}_{2} \mathrm{O}_{7}$. While in the oxidation of $\mathrm{Fe}^{+2}$ with $\mathrm{KMnO}_{4}$, the end point can be detected using $\mathrm{Ta} / \mathrm{Pt}$ system in forward titrations and both $\mathrm{Ta} / \mathrm{Pt}$ and $\mathrm{Ta} / \mathrm{SCE}$ in backward titrations.

\section{Table (2): Features of redox titration curves with Ta-systems as compared

\begin{tabular}{|c|c|c|c|c|c|c|c|c|c|c|}
\hline \multirow{3}{*}{ Reaction } & \multirow{3}{*}{$\begin{array}{c}\text { Oxidizi } \\
\text { ng } \\
\text { agent }\end{array}$} & \multirow{3}{*}{$\begin{array}{l}\text { Vol. } \\
\text { mL }\end{array}$} & \multicolumn{8}{|c|}{ Heights of Potential Jump, mV } \\
\hline & & & \multicolumn{4}{|c|}{ Forward } & \multicolumn{4}{|c|}{ Backward } \\
\hline & & & $\begin{array}{l}\text { Pt/SC } \\
\text { E }\end{array}$ & $\begin{array}{c}\mathbf{T a} / \mathrm{SC} \\
\mathrm{E}\end{array}$ & $\mathrm{Ta} / \mathrm{Pt}$ & $\begin{array}{c}\mathrm{Ta} / \mathrm{A} \\
\mathrm{g}\end{array}$ & $\begin{array}{c}\mathbf{P t} / \mathbf{S C} \\
\mathrm{E}\end{array}$ & $\begin{array}{c}\mathbf{T a} / \mathrm{SC} \\
\mathrm{E}\end{array}$ & $\begin{array}{c}\mathrm{Ta} / \mathrm{P} \\
\mathrm{t}\end{array}$ & $\mathrm{Ta} / \mathrm{Ag}$ \\
\hline
\end{tabular} with those of Pt/SCE system}


TANTALUM AS AN INDICATOR ELECTRODE IN DIFFERENT S...... 87

\begin{tabular}{lllllcccccc}
\hline & & 5.0 & 648 & & 626 & & 742 & 149 & 661 & - \\
$\mathrm{Fe}^{+2} / \mathrm{Fe}^{+3}$ & $\mathrm{KMnO}_{4}$ & 10.0 & 701 & - & 643 & - & 654 & 219 & 491 & - \\
& & 15.0 & 668 & - & 630 & - & 609 & 275 & 495 & - \\
\hline \multirow{2}{*}{$\mathrm{Fe}^{+2} / \mathrm{Fe}^{+3}$} & $\mathrm{~K}_{2} \mathrm{Cr}_{2} \mathrm{O}_{7}$ & 10.0 & 250 & - & - & - & 211 & - & - & - \\
& & 15.0 & 186 & - & - & - & 123 & - & - & - \\
\hline \multirow{2}{*}{$\mathrm{S}_{2} \mathrm{O}_{3} / \mathrm{S}_{4} \mathrm{O}_{6}{ }^{-}$} & & 2.0 & 142 & 563 & 440 & 566 & 215 & 287 & 93 & 429 \\
& $\mathrm{I}_{2}$ & 3.5 & 151 & 414 & 325 & 497 & 190 & 214 & 104 & 322 \\
& & 5.0 & 141 & 446 & 340 & 494 & 163 & 229 & 82 & 355 \\
\hline
\end{tabular}

From the above observations, the shape of the titration curves depends upon the type of the oxidizing and reducing agents used as well as on the direction in which the titration technique was carried out. Moreover, the way in which the electrodes respond to $[\mathrm{Ox}] /$ [Red] ratio before and after the equivalence point differ in most cases from that recorded for Pt/calomel electrode.

\section{3- Application of tantalum electrode in potentiometric titration of ferric iron}

In this study, tantalum electrode is applied as an indicator electrode in the precipitation of ferric iron from neutral solution of its chloride by the addition of $\mathrm{NaOH}$ solutions. The ferric chloride was standardized by reduction with stannous chloride and then titrated with potassium dichromate solution. In case of potentiometric titration of $\mathrm{FeCl}_{3}$ with $\mathrm{NaOH}$ solution, a potential jump occurs at the quantitative precipitation of ferric hydroxide (Figure 11). 


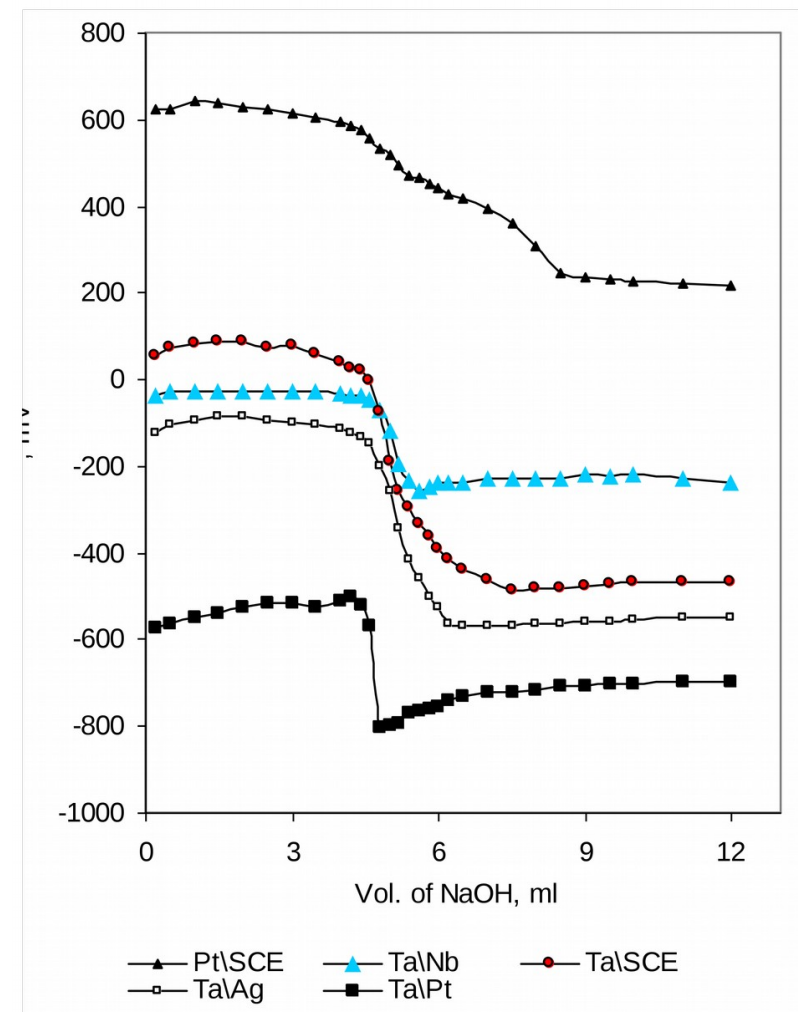

Figure (11): Potentiometric titration curves of $5 \mathrm{ml} 0.0874 \mathrm{~N} \mathrm{FeCl}_{3}$ with $0.0857 \mathrm{~N} \mathrm{NaOH}$.

It was observed that the potential jumps in all systems used are higher than that of the standard Pt/SCE system (Table 3). Also, the experimental equivalence volumes are so near from the calculated one.

Table (3): Comparison of different electrode systems in the precipitation of ferric chloride by the addition of $\mathrm{NaOH}$ solution

\begin{tabular}{cccc}
\hline \multirow{2}{*}{ System } & $\mathbf{P}_{\mathbf{j}}, \mathbf{m V}$ & $\mathbf{C a}$ & $\mathbf{V}_{\mathbf{e q}}, \mathbf{m l}$ \\
\cline { 3 - 4 } $\mathrm{Pt} / \mathrm{SCE}$ & 168 & $\mathbf{E x}$ \\
$\mathrm{Ta} / \mathrm{Nb}$ & 219 & 5.0 \\
$\mathrm{Ta} / \mathrm{SCE}$ & 457 & 5.1 & 5.0 \\
$\mathrm{Ta} / \mathrm{Ag}$ & 418 & & 5.0 \\
$\mathrm{Ta} / \mathrm{Pt}$ & 231 & 5.2 \\
\hline
\end{tabular}


TANTALUM AS AN INDICATOR ELECTRODE IN DIFFERENT S....... 89

$\mathrm{P}_{\mathrm{j}}$, potential jump $\mathrm{V}_{\text {eq, }}$, equivalence volume $\mathrm{Ca}$, calculated $\mathrm{Ex}$, experimental

From the Table, the potential jump descending in the following order:

$$
\mathrm{Ta} / \mathrm{SCE}>\mathrm{Ta} / \mathrm{Ag}>\mathrm{Ta} / \mathrm{Pt}>\mathrm{Ta} / \mathrm{Nb}>\mathrm{Pt} / \mathrm{SCE}
$$

Because of differences in $E^{\circ}$ potentials, the measurement of potential differences between any two indicator electrodes allowed the determination of equivalence points accompanied by special change in potential jump for each system.

\section{Conclusion}

Bimetallic combinations were equally suitable for the determination of equivalence points of mono- basic acids and also with acids neutralizing in more than one step, e.g., $\mathrm{H}_{3} \mathrm{PO}_{4}$ but not with oxalic acid. These combinations fail to analyze a mixture of formic and hydrochloric acids. In oxidation of $\mathrm{S}_{2} \mathrm{O}_{3}{ }^{-}$with $\mathrm{I}_{2}$ solution, the three Ta- systems prove to determine the exact end point. Concerning the oxidation of $\mathrm{Fe}^{++}$with $\mathrm{KMnO}_{4}, \mathrm{Ta} / \mathrm{Pt}$ system can only be used for detecting the end point in forward and backward titrations. While in oxidation of $\mathrm{Fe}^{++}$with $\mathrm{K}_{2} \mathrm{Cr}_{2} \mathrm{O}_{7}$, none of the three systems can be used for detecting the end point. These systems succeeded also to define the end point in the titration of $\mathrm{FeCl}_{3}$ against $\mathrm{NaOH}$ solution.

Hence a Ta/Ag and Ta/ Pt couple can be used instead of the usual Pt/calomel cell, to indicate the end point. The use of such bimetallic combination enables the elimination of the calomel electrode with its salt bridge so that a more easily to handle assembly results. 


\section{References}

1.A. HULANICKI, S. G ąb, Encyclopedia of Analytical Science (2005) 114.

2.E. M. ATTIA, Al- Azhar Bull. Sci. 19(2008) 201.

3.L. XIAO-JIE, B. PENG, F. LIU, Y. QIN, Sensors and Actuators B: Chemical 125 (2007) 656.

4.A. IGLESIAS, R. LÓPEZ, D. GONDAR, J. ANTELO, S. FIOL, F. ARCE, Chemosphere 76 (2009)107.

5.A. BARAKA, A.I. ABDEL-ROHMAN, E.A. EL-TAHER, Mater. Chem. Phys. 9 (1983) 447.

6.A.A. ATTIA, Electro. Chim. Acta 47(2002) 1241.

7.L. TORTORA, M. STEFANELLI, M. MASTROIANNI, L. LVOVA, C. D. NATALE, A. D’AMICO, D. FILIPPINI, I. LUNDSTRÖM, R. PAOLESSE, Sensors and Actuators B: Chemical, In Press, Accepted Manuscript, Available online 28 May 2009.

8.B. KURZAK, A. WOŹNA, A. KAMECKA, K. KURZAK, Polyhedron 27 (2008)3053.

9.H. PODSIADŁY, Z. KARWECKA, Polyhedron 28(2009)1568.

10. G. AMBROSI, M. FORMICA, V. FUSI, L. GIORGI, E. MACEDI, M. MICHELONI, R. PONTELLINI, Inorg. Chim. Acta, 362 (2009) 3709.

11. C. SÁNCHEZ-PEDREÑO, J.A. ORTUÑO, J. HERNÁNDEZ, Analy. Chim. Acta 333(1996)107.

12. G. BAZYLAK, L. J. NAGELS, J. Chromatography A 973(2002)85.

13. L. CHEN, H. JU, X. ZENG, X. HE, Z. ZHANG, Anal. Chim. Acta 437 (2001) 191.

14. A.M. MAZLOUM, H. DEHGHANI, M. JALAYER, H.R. ZARE, Anal. Sci. 20 (2004) 1667.

15. M.K. AMINI, A. RAFI, I. MOHAMMADPOOR-BALTORK, Anal. Lett. 35 (2002) 1795.

16. X.B. ZHANG, Z.X. HAN, Z.H. FANG, G.L. SHEN, R.Q. YU, Anal. Chim. Acta 562 (2006) 210.

17. L. ZELENKA, M. SAK-BOSNAR, N. MAREK, B. KOVACS, Anal. Lett. 22 (1989) 2791.

18. M. GERLACHE, Z. SENT"URK, J.C. VIRE, J.M. KAUFFMANN, Anal. Chim. Acta 349 (1997) 59. 
19. S. MARTINEZ-BARRACHINA, J. ALONSO, L. MATIA, R. PRATS, M. D. VALLE, Anal. Chem. 71 (1999) 3684.

20. J. SANCHEZ, M. D. VALLE, Electroanalysis 13 (2001) 471.

21. R. MATESIC-PUACA, M. SAK-BOSNARB, M. BILICA, B.S. GRABARIC, Sensors and Actuators B 106 (2005) 221.

22. R. MATESIC-PUACA, M. SAK-BOSNARB, M. BILICA, B.S. GRABARIC, Electroanalysis 16 (2004) 843.

23. K. TØMMERAAS, W. PER-OLOF, Carbohydrate Polymers 77(2009)194.

24. C. ERBIL, B. TERLAN, Ö. AKDEMIR, A. T. GÖKÇEÖREN, J. European Polymer 45(2009)1728.

25. Z. KUN-YU, AH. HUI-PING, Z. LI-JUAN, C. QI-YUAN, Transactions of Nonferrous Metals Society of China 18(2008)1285.

26. A. BARAKA, A.I. ABDEL-RAZIK, A.I. ABDEL-ROHMAN, Surf. Technol. 25(1985)31.

27. S. SHAHINE, M.S. EL BASIOUNY, J. Electroanal. Chem.108 (1980)271.

28. VOGEL, Quantitative Inorganic Analysis, The English Language Book Society, Longman (1978) p. 600.

29. H. H. WILLARD, N. H. FURMAN. Elementary Quantitative Analysis. Education Manual EM 457. (1940)117.

30. P. W. ATKINS, Physical Chemistry Atkins $6^{\text {th }}$ ed. Oxford (1998) p.934.

31. A. P. KRESHKOV, A. A. YAROSLAVTSEV Course of Analytical Chemistry vol.2 quntitative analysis, (1977) p. 296.

32. A. A. SOLIMAN, M. Sc Thesis, Al- Azhar University (1982)

33. R. M. SALEH, Ph.D. Thesis, Cairo University (1970).

34.S. A. DARWISH, R. SALIM, Microchem. 1(1973) 670.

35.U. R. EVANS, The Corrosion and Oxidation of Metals $2^{\text {nd }}$ ed. Arnold, London (1976) p.34. 